Aleksander Lorenčič

\title{
Studying the Economic Transition - Challenges, Problems and Results
}

\begin{abstract}
IZVLEČEK
PROUČEVANJE GOSPODARSKE TRANZICIJE - IZZIVI, ZAGATE IN REZULTATI

$V$ pričujočem prispevku avtor predstavi izzive, zagate in spoznanja, s katerimi se je soočal pri raziskavi in proučevanju slovenske gospodarske tranzicije. Cilj raziskave, ki velja za, pionirsko' na področju zgodovinopisja, je bil analitično interpretirati proces gospodarske tranzicije in poudariti njene temeljne posebnosti, zakonitosti, nosilce ter rezultate. Rezultat raziskovanja je znanstvena monografija in številni znanstveni ter strokovni članki s področja gospodarske tranzicije.
\end{abstract}

Ključne besede: Slovenija, osamosvojitev, gospodarstvo, tranzicija

\section{ABSTRACT}

In the following article the author presents the challenges, problems and findings that he encountered while researching and studying the Slovene economic transition. The aim of this research, which is considered 'pioneer' in the field of historiography, was to analytically interpret the process of economic transition and point out its fundamental characteristics, rules, agents and results. The result of the research is a scientific monograph and a number of scientific and technical articles in the field of economic transition.

Key words: Slovenia, independence, economy, transition

In historiography, there are a few so clear and in terms of time so accurately delimited milestones as the year 1991 in Slovene history. With the proclamation of autonomy and independence, we, the Slovenians, have taken our destiny completely into our own hands for the first time, which is why this period, without a doubt, deserves special attention in the field of historiographical research. Despite the fact that from the viewpoint of historiography it lasts only for a short period of two decades and despite the processes many of which have not yet been concluded, this period has to be systematically researched by means of the historiographic method. ${ }^{1}$

* PhD, Pokrajinski muzej Ptuj-Ormož, Muzejski trg 1, SI - 2250 Ptuj, aleksander.lorencic@ pmpo.si, aleksander.lorencic@pmpo.si

1 Aleksander Lorenčič, "Slovensko gospodarstvo med tranzicijo in globalno krizo (1990-2010)," 
The study of the period in question, which - due to the so-called historical distance - requires taking into account several factors that influence the scientific research and the presentation of events (from the question of sources, to documentation and the influence of politics), is in many countries no longer a novelty. The importance and role of economic history as a sub-discipline or a specific genre within the historical science is not given much attention. In general, the economic historiography has been for decades on the outskirts of interest in the professional circles. In the nineties of the $20^{\text {th }}$ century, there has been a restructuring of the economic historiography, which coincided with the arrival of the younger researchers. In fact, only two researchers, Žarko Lazarević and Jože Prinčič, both members of the Institute of Contemporary History, have systematically and actively dealt solely with the economic history. ${ }^{2}$ Precisely the Institute of Contemporary History has decided to systematically focus also on the period after 1990, and for that purpose employed two young researchers. The result of this decision is, among others, a scientific monograph titled Prelom starim in začetek novega: Tranzicija slovenskega gospodarstva iz socializma $v$ kapitalizem (1990-2004) (A Break With the Old and the Beginning of the New: The Transition of Slovene Economy from Socialism to Capitalism (1990-2004)), which represents a significant contribution to the Slovenian economic historiography. ${ }^{3}$

Writing about the Slovenian economic transition as a historian has not been an easy task, but it has nevertheless represented a great challenge. I agree with Ivan T. Berend, who in 2009 in the preface of his book wrote that to write about the present or "the unfinished present" is the same as "shooting a moving target". ${ }^{4}$ The fact is that anyone who reads the newspapers or watches the daily-news programs is aware that in the last few years we have been "bombarded" on a daily basis with the information that more or less pertains to the economic transition or its consequences. What is more, the market is full of literature and articles (non-technical, technical and scientific) which deal with the process of economic transition as a whole or focus only on individual problems. I have to admit that due to the multitude of often contradictory information (the opinions of the economic profession are frequently divided as well), it was rather difficult to create a relevant and comprehensive image of such a complex process as the economic transition. As far as the methodological approaches are concerned, due to the legal restrictions on the access of the archival materials, the research and insights are mostly not based on the classic historical (archival) sources. However, judging by the previous research experience regarding the period after the

in: Vizija raziskav slovenske gospodarske in družbene zgodovine, ed. Darja Mihelič (Ljubljana: Založba ZRC, 2014), 311, 312.

2 Žarko Lazarević, "Identitetne zadrege slovenskega ekonomskega zgodovinopisja," in: Podobe modernizacije. Poglavja iz gospodarske in socialne modernizacije Slovenije v 19. in 20. stoletju, eds. Žarko Lazarević and Aleksander Lorenčič (Ljubljana: Inštitut za novejšo zgodovino, 2009), 38.

3 Aleksander Lorenčič, Prelom s starim in začetek novega. Tranzicija slovenskega gospodarstva iz socializma v kapitalizem (1990-2004) (Ljubljana: Inštitut za novejšo zgodovino, 2012).

4 Ivan T. Berend, From the Soviet Bloc to the European Union. The Economic and Social Transformation of Central and Eastern Europe since 1973 (New York: Cambridge University Press, Cambridge, 2009), 14. 
Slovenian independence, it is clear that the classic method of studying historiography has to be upgraded with the new methodological approaches. One of the reasons is also the occurrence of informational and communicational revolution after 1990, enabling quicker access to various sources (e.g. the digitalization of different documents), and at the same time triggering the emergence of new industries. The second reason lies in the fact that after 1991, only the state bodies and institutions the documentation of which is more or less accessible also today were legally required to hand over their material to the archives in a given period of time. Furthermore, it is known that a great deal of material was destroyed, be it due to negligence or on purpose, for instance the material of various companies. What is interesting as well is the information presented by an archivist from the Regional Archives Maribor, Gordana Š̈vegeš, who was wondering about the whereabouts of the documentary material of the Prekmurian companies that went bankrupt in the nineties. Inquiring with different bankruptcy managers and former company directors yielded no new information for the archivist, and the most frequently heard answer was "we do not know". The ones responsible also ignored the laws. "Where would we be if we complied with all the laws and regulations!" a director replied to the archivist. We have to bear in mind that the Prekmurian example is certainly not the only one and, as written by the archivist Š̈ovegeš in 2003, it is "generally known that the material of the former companies in public ownership is being massively destroyed even today". 5 Similar things happened with the Communist Party material or the CK ZKS (Central Committee of the Slovene Communist Party) material. Many municipal committees (18 exactly) did not hand over their material. As written by Darinka Drnovšek from the Archives of the Republic of Slovenia, some people "destroyed the documentation simply because they feared that under the new political circumstances these archives would be taken advantage of", others stored the documents somewhere (in the basement or the attic) and "the new leaderships did not want to have anything to do with it". ${ }^{6}$ Archivists will thus have a lot of hard work to make sure that the archival material ends up in the archives in the most satisfactory form possible - at least a greater part of what has not been destroyed. Since the problem of transition is distinctively multidisciplinary, the methodological approach was highly interdisciplinary as well. As a historian, I have given priority to the established method of historical profession, meaning that on the basis of a detailed study of all the possible and available sources and especially the critical analysis of the latter, I have tried to determine, confront and confirm as many material facts of the process in question as possible. The economic, political, sociological, legal and anthropological conceptualizations of the thematic, theoretical and methodological bases for studying the transition were all

5 Gordana Šövegeš Lipovšek, "The archival material of the Prekmurian companies," in: Arhivi in arhivsko gradivo v času tranzicijskih sprememb/Infoarh, eds. Mija Mravlja and Andrej Nared (Ljubljana: Arhivsko društvo Slovenije, 2003), 59-61.

6 Darinka Drnovšek, "The material of the Communist Party in the time of transition," in: Arhivi in arhivsko gradivo v ćasu tranzicijskih sprememb/Infoarh, eds. Mija Mravlja and Andrej Nared (Ljubljana: Arhivsko društvo Slovenije, 2003), 67-70. 
taken into account. The monograph deals with all the fundamental processes of the economic transition. Up until now, especially the economic profession has dealt with individual problems and processes of this period, but not in a manner in which the problem of economic transition is presented in this work. As already pointed out, the monograph is written in accordance with the rules of historical profession and it represents a comprehensive account of the problem of the economic transition. This means the inclusion of all the relevant aspects of the problem, since only this way we can expect a comprehensive and authentic reconstruction of the complexity of the economic transition.

The decision to become a sovereign and independent country has made it possible for Slovenia to engage in its own economic policy and to take over the responsibility for its own economic development. By the end of 1992 Slovenia had already been recognized by one hundred countries and become a member of the UN and its specialized organizations; by 1996 she had become a member of almost all the significant economic associations (European Bank for Reconstruction and Development, International Monetary Fund, World Bank and International Finance Corporation, GATT, WTO, EFTA and CEFTA). Slovenia was in this way "fastened with a safety belt" to the West and thus protected from the war that took place in parts of the former Yugoslavia. The biggest strategic objective of the Republic of Slovenia was, due to its close political, cultural and economic co-operation with Europe, full membership of the EU, which was realized on 1 May 2004. The only organization which Slovenia was unable to become a member of quite so rapidly was the OECD which unites the economically most developed countries in the world (Slovenia did not become a member until 2010). ${ }^{7}$ Slovenia was one of the first to pass over the period of transformation depression, which was typical for transition economies in the early nineties, as the recovery of economic growth through the revival of domestic demand took place in mid-1993. Slovenia relatively quickly exceeded the pretransitional level of economic activity - the 1990 level of pretransitional development from in 1996 and the 1987 level in $1998 .^{8}$

Throughout the whole economic transition process, the process of privatization has caused by far the most trouble and stress in political and economic circles and to the population as a whole. It has certainly proved to be the central and most demanding of all the transition processes. Let us say right away that this is not just a Slovenian particularity, but similar patterns were also seen in other post-communist countries. Privatization of socially-owned property was the process that affected the population most deeply. Legally, the process took place in several steps. In autumn 1991 two acts relating to the privatization of apartments and denationalization were adopted. The Ownership Transformation of Companies Act (OTCA) was adopted in November $1992 .{ }^{9}$ The basic principle of the privatization of apartments and apart-

\footnotetext{
7 Lorenčič, Prelom s starim in začetek novega, 455, 456.

8 Ibid, 456.

9 Ibid, 457, 458.
} 
ment houses was the equalisation of the right to purchase an apartment for all those citizens who held housing rights on the day the Housing Act was implemented. An even greater problem was caused by denationalization or the implementation of the latter which was often the subject of polemics and various accusations, particularly by expropriators who set up the Association of Expropriated Property Owners of Slovenia. In their view, the return of nationalized property took place too slowly. The property was returned to the former owners or their heirs "in kind" and if that was not possible, compensation was provided. Return of the property "in kind" provoked most outrage when the Act was adopted, which only intensified when the act was put into practice. At the end of March 2007, the percentage of settled cases at the national level was 94.9. The objective of denationalization and privatization of apartments should be to establish ownership and to redress a wrong, but often just the opposite has happened. Legislation in the form it was adopted has actually led to a number of new injustices. Let us look at, for example, the returning of apartments in kind, even when they were occupied by residents with housing rights to them. Slovenia was the only one of all the transition countries to implement this. Many people in this situation were unjustly treated and indeed exploited by the new owners, but the state has done very little to help and has actually continued to write acts that have done very little to prevent a number of malversations. The government had by far the most problems with the adoption of the privatization of companies act. The proposals concerning the method of privatization, put forward by Aleksander Bajt and Ivan Ribnikar, were given little serious discussion at government level. However, within the coalition there was a conflict between two completely different economic and political concepts and in the end, some sort of interim model between Mencinger's and Sachs's proposal prevailed. During the period from 1990 to the adoption of the OTCA at the end of 1992, many companies converted their status, increased in capital or reorganized on the basis of the Yugoslav legislation of that time. Because at that time the state had not yet fully established the institution of control over the status and financial-capital changes of the companies that had social capital, there was, of course, wide scope for abuse. During this period, so-called "wild privatization" took place. In order to prevent such abuses, in December 1990 two state institutions that were supposed to supervise and regulate the process of privatization and restructuring were established. The Agency of the Republic of Slovenia for Restructuring and Privatization has supervised and followed the process, prepared guidelines and verified the privatization programmes, while The Fund of the Republic of Slovenia for Development has restructured companies. The latter also became the owner of companies and could negotiate and sign sales contracts. Today we are often witness to accusations about fearsome social stratification, stories about management takeovers and similar. What we have to realize is that the situation in society and the economy today is not a result of what took place yesterday or in recent years, but that we have to look for answers at the beginning of our transition story. The lion's share of controversial privatizations can reliably be attributed to delays in the long-term process of the adoption of The Ownership Transformation of Companies Act. We 
cannot affirm that the so-called "wild privatization" ran by the so-called Marković acts, because if that were the case, it certainly would not be controversial and illegal. In fact, it only referred to a legally unresolved Marković conception of privatization. One fact we cannot dispute is that while politicians were arguing and discussing possible solutions to the problems of ownership transformation, some had already seized a considerable section of socially-owned property. Let us recall the two, so-called "higher forms" of abusing social property, which some were taking advantage of when relevant legislation had not yet been adopted. The first is by-pass companies. This was a well-known and widespread phenomenon of establishing a company in private ownership, set up by workers employed in a social enterprise with the same or similar subject of business for which the social company was registered. The social company was then run down, until they entered liquidation and bankruptcy. This serves as a clear case of "wild privatization". The other example represents a free transfer of social capital, which refers to the second paragraph of article 145 of the Law on Enterprises from 1990. The described transfer of the capital, even if carried out between companies that were in social ownership, was illegal. In this way, mixed companies now became social property owners in social companies and by doing so also indirectly privatized social companies without the Privatization Act, which was unacceptable and illegal. Of course, there were also other forms of abusing social property, such as unfounded abatement of debts, improper profit-sharing and unpaid transfer of capital. In any case the fundamental cause of "wild privatization" was the fact that the privatization of public property was possible from the outset, without adequate rules and regulations. Moreover, despite warnings from the relevant institutions, the Slovenian parliament did not react. The same was also true in the case of the aforementioned article 145. b of the Law on Enterprises, which allowed free transfer of social property under one's own will and which the Slovenian parliament did not withdraw or supplement in time. According to data from the Agency for Auditing, during the period from 1 January 1990 to 31 December 1992 there was a deficit of socially-owned property to the value of 86,174 million Slovenian Tolars or, if revalorized, the value of $1,238,454,581.87$ Euros. In total, according to the audit, the deficit of socially-owned property in the period from 1 January 1990 to 31 July 2004 was to the value of 104 billion-Slovenian Tolars. ${ }^{10}$ In any case, a small proportion of the population managed to recover significantly during this period. The long-term adoption of the appropriate legislation has thus had serious consequences. However, it is possible to understand the governing policy of that time, at least to a certain extent. According to many, the privatization law which was eventually adopted was the best of all those suggested. Certainly, if we accept that it is better to pause and reflect rather than make hasty decisions, it was certainly preferable to pass an appropriate law later than rush through an unsuitable one. It is also true, as Jože Mencinger admits, that the government at that time was a group of amateurs and either politicians or the appropriate bodies were able to deal with the

10 Ibid, 268, 458-60. 
situation (this was the same in all transition countries). In defence of the government at that time, we should also consider that processes such as the transition do not happen often and there is no manual for producing perfect results. All this can be understood, but what is harder to accept is the fact that consequently there were numerous abuses and economic benefits to some, which, of course, is the other, darker side of the story. Anyway, the finally adopted OTCA provides companies with seven methods of achieving ownership transformation and combines the elements of two different approaches, namely the decentralized approach, where most of the initiatives and decisions came from companies and the mass privatization of part of the shares so that they can be divided among citizens in exchange for certificates. Despite the long-term adoption of the OTCA, some flaws remained. The legislature had, inter alia, restricted audits to a three-year period from 1990 to 1992, assuming that the pre-privatization audit procedures would be completed by the end of 1994, which certainly was not the case. It turns out that the deadlines set by the legislator were missed completely and impossible to execute in practice. Inappropriate rules of law, among other things, triggered once again the unnecessary "legalization" of "wild privatization" after 1 January 1993 and thus the establishment of by-pass companies and similar malversations also continued after 31 December $1992 .{ }^{11}$ Up to the beginning of the operation of the Agency of the Republic of Slovenia for the Auditing of Ownership Transformation of Companies in August 1996, so after a period of almost three years, it was not possible to initiate an appropriate audit of previous privatization or to act according to the OTCA. One of the methods of becoming rich in Slovenia was provided by certificates. The majority of Slovenian citizens sold the certificates quickly, thinking they were nothing more than a worthless piece of paper. Since 1993, however, the market in proprietary certificates has flourished. Brokerage firms were formed and a handful of better-informed citizens purchased the certificates at low value and exchanged them later for shares; while the share values increased (mostly), their owners became increasingly richer. The processes of ownership and privatization have taken a relatively slow course. Up to 7 November 1994, 700 companies submitted their programmes for restructuring to The Agency of the Republic of Slovenia for Restructuring and Privatization, which was 52 per cent of all those liable for transformation by law. In early May 1998 the Act Concluding Ownership Transformation and Privatisation of Legal Entities Owned by the Development Corporation of Slovenia came into force, which defined the transition from the decentralized to centralized form of privatization. In the six years of the process, almost all of the companies with social capital carried out ownership transformation, and only a small number of companies chose not to privatize, because of their own inactivity, or other objective reasons. By completing the process of the ownership transformation of companies, the first phase of the transition process was completed, the aim of which was to push Slovenia into common global trends and economic flows and also enter into the European integration process. With the completion of

11 Ibid, 461. 
the process a new investment cycle was also initiated, thereby increasing not only the economic growth and employment but also the share of foreign investments. After the formal completion of the process of ownership transformation of companies, it was necessary to complete the second part of the transition process, namely the privatization of state property. The sale of state property represents another form of "wild privatization". The majority of capital shares in the period 1995-2005 were sold without public bids, therefore non-transparently. The privatization method was otherwise well-intentioned and allowed a high level of worker and employee involvement in ownership changes, but the good intentions came to nothing. During the privatization process, the participation of internal owners (non-management employees) and state funds declined, but the participation of investment firms and managers increased. Slovenia's entry into the European Union marked the formal end of the transition, however the emphasis here is on formal, because only after that period did the privatization prey or its results begin to show. We have been witness to frequent stories of management takeovers, numerous accusations and polemics. These events served the politicians mostly for the purpose of collecting votes; let us not forget the story of the sale of Mercator. The management buyouts did not start in BTC, Iskra, Merkur or Laško. A unique case of a Slovenian management buyout took place in 1995 in the company Agroruše. It is reasonable to add that where privatization was carried out fairly and by the will of the people, where there was no double crossing and injustice and in particular, where intentions were entirely honest, those who undertook the process of ownership transformation were able to live with an entirely different spirit and even better. Unfortunately, it transpired that in a large number of Slovenian companies the motivating principles of the managers were less than fair, accruing benefits and greed. As previously mentioned, things were not as closely regulated as they should have been at the very beginning. We are thinking in particular here of the legal aspect; little has changed. There were many "loopholes" in the acts and many of those who are now accused of all kinds of abuses, have acquired their wealth, so to speak, legally. A large share of the responsibility lies with the legal system and politicians, because the National Assembly is a place where acts are proposed and adopted. As mentioned previously, many of the deficits in the first period of transition occurred because legislation was inadequate or pending, as well as calls to action being largely ignored. In the first phase of transition, politicians behaved - except in the election period, obviously - as if wild privatization were only an idea, completely foreign to the Slovenian economy. If we mention the later period and the aforementioned notorious manager's takeovers, the fact is that a great deal of them also happened with the generous help of the politicians. Whether we like it or not, politics and the economy are co-dependent areas, as was illustrated so strikingly during the process of privatization, since the latter often served policy as a tool to increase influence. Even in stories that were seemingly all about the national interest, it transpired that the interests of individuals prevailed. The concept of policy in its narrow sense is defined as directing society with the help of the state. And given the fact that socially-owned property has mostly landed in the hands of a handful of 
people, that we are witnessing distinctive social stratification, that many do not believe in a state governed by the rule of law and the like, it is clear that the policy has not entirely successfully directed Slovenian society to the intended goal. The restructuring of the Slovenian economy can certainly not be described as successful, at least not entirely. If not before, this statement proved to be true when after the first quarter of 2009, Slovenia officially lapsed into recession brought about by the global financial and economic crisis. The recession occurred for the first time since 1993, when our country passed over to the transformation recovery and we again witnessed a decline in economic activity, the failure of companies and high unemployment. Crises, which are an integral part of economic life, highlight accumulated economic imbalances or irregularities, and this is exactly what happened in Slovenia. Many of the companies which were not successfully and suitably restructured during the transition have collapsed. Many were forced to reorganize and restructure. ${ }^{12}$

With regard to the conclusions and results of the research connected to my study of the economic transition, be it individual articles or the monograph Prelom starim in začetek novega (A Break With the Old and the Beginning of the New), the fact is that from today's perspective and with new knowledge I would have written some things differently. However, this is precisely the essence of the research and historiography as such: it is a vital process that takes the existing knowledge and constantly upgrades it in the presence of new knowledge. I believe the crucial thing in understanding the economic transition is for the researcher to understand the process and put it in a broader context. Taking an example of the grounds or causes for the socio-political and economic changes, we must bear in mind that, from a broader perspective, this was the time of the collapse of the Soviet Union, the collapse of the bipolar division of the world and the time in which socialism became obsolete. In Yugoslavia, the political, transnational, cultural and economic disagreements lead to the desired goal - the Slovenian independence and the transition to a capitalist system. Researching the economic transition as a contemporary researcher, I am aware of the fact that capitalism is a causal-consequential process and that Slovenia cannot avoid external influences, on which it ultimately depends. Economic crises are an integral part of the economy; the two crises Slovenia has faced in the last 25 years - the transitional and the current one - do not have the same reasons for their occurrence, but their consequences for the population are similar: the bankruptcies of many companies, unemployment, the problems of the banks, etc. The crisis that occurred in 2008 is the third great crisis in the last century and a half. Comparing the crisis that hit the countries with the Slovenian population after the collapse of the Vienna Stock Exchange in 1873, the crisis that was the result of the stock market crash on Wall Street in 1929 and the current crisis, the fact is that all three of them have their origin in the financial sector, because they are the consequence of the financial, credit and investment speculations, and they all occurred after periods of outstandingly positive financial and economic trends. The main difference between the transitional crisis

12 Ibid, 461-64. 
on the one hand, and the global financial and economic crisis on the other is that the former had regional, while the latter had global dimensions. In 1991, Slovenia entered the world of capitalism, which was also facing certain changes that ultimately lead to the outbreak of the last great crisis. If we consider the events from a broader perspective, we discover that in the field of capitalism, especially after the outbreak of the oil crisis in 1973, there has been a major shift in mentality, leading to the belief that the role of state and interventionism are not essential or important for the economy. Neoliberalism occurred: an economic-political paradigm which advocates minimizing the role of state in the economy. The economist Davorin Kračun believes that neoliberalism received political support with the election of President Reagan in the USA and reached its peak at the end of the 1980 with the so-called Washington Consensus, which represented a recipe for the countries in transition. ${ }^{13}$ Kračun believes that "under these circumstances, the neoliberal economic-political paradigm was fairly successful also because it coincided with the collapse of the Eastern Bloc and the expansion of the global market to the once impregnable fortresses of Russia and China". Moreover, in his opinion, the informational and communicational revolutions paved the way for the entirely new industries. ${ }^{14}$ Ivan T. Berend, a comparative historian of the Central and Eastern Europe, is of similar opinion, and he believes that capitalism has changed and since the 1970s has definitely not been the same. "The developed European countries have been deindustrialized, the industry has lost its significance and in the most developed Western countries only 18 percent of the active population works in the industry. The financial sector, including banks, financial institutions, insurance companies and the real estate sector, grows six time faster than the real economy and its assets are three or four times larger than the entire gross domestic product of the European Union. I am talking about the deindustrialized, excessively financially controlled economy, which was very fragile and susceptible to the financial panic that occurred. From 1980 onwards, the entire system has been deregulated: all the regulations implemented in the 1930 and after the Second World War with the Bretton Woods Agreement, including the lessons learned from the Great Depression, have been eliminated. Neoliberalism was convinced that it solved the problems of the crises and that they will not occur anymore. The leading economists of the Chicago School advised the governments that we no longer need the straightjacket of regulation," believes Berend. ${ }^{15}$ In Slovenia, we were not fully aware 25 years ago what the transition to capitalism will bring. During this period, capitalism has changed in certain aspects as well. The financial capitalism prevails, which affects the social differences and rivalry even more. 25 years of independence is a relatively short period and it seems that after so many years of being an

13 Sonja Ploj Ratajc and Vanessa Čokl, "An interview with Davorin Kračun," V soboto/Večer, 28 July 2012, 3-5.

14 Ibid, 3.

15 Saša Vidmajer, "An interview with Ivan T. Berend," Delo/Sobotna priloga, accesed 25 March 2012, http://www.delo.si/zgodbe/sobotnapriloga/zgodovinar-ivan-t-berend-krizo-je-povzrocila-periferna-mentaliteta.html. 
independent country we have only begun to learn about the negative aspects of the capitalist system, of which we expected so much when we gained independence. Today, this strongly shows in the helplessness and despair of people. It is often said that the Slovenian constitution writes about the implementation of the market economy, while in reality, we have run into the cruel capitalist economy. The romantic ideas make it that much harder to accept the fact that in 1991, Slovenia did not only gain independence, but also transited to the capitalist system with all of its positive and negative characteristics about which we listen on a daily basis. ${ }^{16} 1991$ marks a significant turning point in our history. Attaining independence, gaining international recognition and entering into various international bodies, with the pinnacle - entrance into the European Union in 2004 - are achievements our ancestors could only dream of. If we draw a line, the process of economic transition and the transition to an open socio-market economy in Slovenia deserves positive historical appraisal with a black dot that, as in other transition countries, points to missed strokes and opportunities. This is understandable, because a process as complex as the transition cannot be accomplished entirely as planned or intended, since matters in practice often do not run as smoothly they are written in textbooks and acts of law.

\section{Sources and Literature}

Literature:

- Berend, T. Ivan. From the Soviet Bloc to the European Union. The Economic and Social Transformation of Central and Eastern Europe since 1973. New York: Cambridge University Press, Cambridge, 2009.

- Drnovšek, Darinka. "The material of the Communist Party in the time of transition." In: Arhivi in arhivsko gradivo v času tranzicijskih sprememb/Infoarh, eds. Mija Mravlja and Andrej Nared, 67-70. Ljubljana: Arhivsko društvo Slovenije, 2003.

- Lazarević, Žarko. "Identitetne zadrege slovenskega ekonomskega zgodovinopisja." In: Podobe modernizacije. Poglavja iz gospodarske in socialne modernizacije Slovenije v 19. in 20. stoletju, eds. Žarko Lazarević and Aleksander Lorenčič, 13-57. Ljubljana: Inštitut za novejšo zgodovino, 2009.

- Lorenčič, Aleksander and Lojze Javornik. "Slovenci imamo mitičen odnos do vsake državne tvorbe: Zgodovinar Aleksander Lorenčič o čudnosti čudenja liberalnemu kapitalizmu, slepega prevzemanja ideologije od starejših generacij in o slovenskem zaostajanju zaradi neenotnosti o temeljnih ekonomskih nalogah in odnosu do tujih naložb." Finance. Priloga Manager: revija za podjetne, 17 June 2016, 16-19.

- Lorenčič, Aleksander. Prelom s starim in začetek novega. Tranzicija slovenskega gospodarstva iz socializma v kapitalizem (1990-2004). Ljubljana: Inštitut za novejšo zgodovino, 2012.

- Lorenčič, Aleksander. "Slovensko gospodarstvo med tranzicijo in globalno krizo (1990-2010).” In: Vizija raziskav slovenske gospodarske in družbene zgodovine, ed. Darja Mihelič, 311-325. Ljubljana: Založba ZRC, 2014.

- Ploj Ratajc, Sonja and Vanessa Čokl. "An interview with Davorin Kračun." V soboto/Večer, 28 July 2012,3-5.

16 I have summed up my views on the development during the 25 years of independence in an interview for the newspaper Finance - Aleksander Lorenčič and Lojze Javornik, "Slovenci imamo mitičen odnos do vsake državne tvorbe: Zgodovinar Aleksander Lorenčič o čudnosti čudenja liberalnemu kapitalizmu, slepega prevzemanja ideologije od starejših generacij in o slovenskem zaostajanju zaradi neenotnosti o temeljnih ekonomskih nalogah in odnosu do tujih naložb," Finance. Priloga Manager: revija za podjetne, 17 June 2016, 16-19. 
- Š̈övegeš Lipovšek, Gordana. "The archival material of the Prekmurian companies." In: Arhivi in arhivsko gradivo v času tranzicijskih sprememb/Infoarh, eds. Mija Mravlja and Andrej Nared, 59-61. Ljubljana: Arhivsko društvo Slovenije, 2003.

- Vidmajer, Saša. "An interview with Ivan T. Berend.” Delo/Sobotna priloga. Accesed 25. March 2012. http://www.delo.si/zgodbe/sobotnapriloga/zgodovinar-ivan-t-berend-krizo-je-povzrocila-periferna-mentaliteta.html.

$\frac{\text { Aleksander Lorenčič }}{\frac{\text { PROUČEVANJE GOSPODARSKE TRANZICIJE - IZZIVI, ZAGATE IN REZULTATI }}{\text { P O V Z E T E K }}}$

$\mathrm{V}$ pričujočem prispevku avtor predstavi izzive, zagate in spoznanja, $s$ katerimi se je soočal pri raziskavi in proučevanju slovenske gospodarske tranzicije. Cilj raziskave, katere rezultat je več znanstvenih in strokovnih člankov ter znanstvena monografija Prelom s starim in začetek novega, ki velja za ,pionirsko' na področju zgodovinopisja, je bil analitično interpretirati proces gospodarske tranzicije in poudariti njene temeljne posebnosti, zakonitosti, nosilce ter rezultate. Rezultat raziskovanja je znanstvena monografija in številni znanstveni ter strokovni članki s področja gospodarske tranzicije. Pisati o slovenski gospodarski tranziciji kot zgodovinar je bilo vse prej kot lahko delo, a mi je predstavljalo velik izziv. Ivan T. Berend meni, da je o dogodkih iz sedanjosti oziroma o "nedokončani sedanjosti" pisati tako, kot da bi "streljal na premikajočo se tarčo". Dejstvo je, da vsak, ki prebira časopisje ali gleda dnevno-informativne oddaje, ve, da smo bili zadnja leta tako rekoč vsak dan "bombardirani" s številnimi informacijami, ki so se tako ali drugače navezovale na gospodarsko tranzicijo oziroma njene posledice. Poleg tega je na trgu ogromno literature in člankov, poljudnih, strokovnih in znanstvenih, ki celostno ali po posameznih problemih obravnavajo proces gospodarske tranzicije. Priznati moram, da si je bilo v tej množici podatkov, ki so si pogosto nasprotujoči (tudi ekonomska stroka je v mnenjih pogosto deljena), zelo težko ustvariti relevantno, celostno podobo o tako kompleksnem procesu, kot je gospodarska tranzicija. Pred 25 leti se v Sloveniji nismo zavedali oziroma si je bilo težko predstavljati, kaj bo prehod v kapitalizem v celoti prinesel. Tudi kapitalizem se je v tem obdobju v določenih pogledih spremenil. Prevladuje finančni kapitalizem, ki še toliko bolj vpliva na socialne razlike in tekmovalnost. Četrt stoletja samostojnosti je relativno kratka doba in zdi se, da šele po toliko letih samostojne države spoznavamo negativne plati kapitalističnega sistema, od katerega smo ob osamosvojitvi toliko pričakovali. To se danes izrazito kaže kot nemoč in brezup ljudi. Pogosto je slišati, da smo v Sloveniji v ustavo zapisali, da uvajamo tržno gospodarstvo, zašli pa smo v kruto kapitalistično gospodarstvo. Zaradi romantičnih predstav je toliko težje sprejeti dejstvo, da se Slovenija leta 1991 ni samo osamosvojila, temveč je prešla tudi v kapitalistični sistem z vsemi pozitivnimi in tudi negativnimi lastnostmi, o katerih danes vsakodnevno poslušamo. 